\title{
Anna Klindt Sørensen, Birgitte Kristensen og vildnisset midtimellem \\ - interview med kunstneren Birgitte Kristensen
}

Af Ane Bülow

Vildnis og selviscenesattelse, portratforskydninger og labyrintiske vandringer med indbyggede benspand. Billedkunstner Birgitte Kristensen har med video, mobler, fotografi, malevi, lyd og lagkage lavet en udstilling der tematiserer portretteringens udfordvinger og dilemmaer, berunder portrattets problematiske forbold til troverdighed og samfundshistorie. Udstillingen Anna Klindts 9 Haver er et dobbelteksponevet billede: bag portrattet af billedkunstneren Anna Klindt Sørensen, ses Birgitte Kristensens tydelige aftryk, og bag dette ses endnu et lag: beskuevens eget.

Udstillingen er netop blevet præmieret af statens kunstfonds billedkunstudvalg.

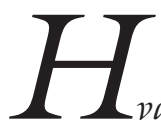

vad var din indgang til at arbejde med Anna Klindt Sorensen, og bvordan har projektet udviklet sig?

Jeg flyttede selv til Ry-egnen, hvor Anna Klindt levede, for ca. 5 år siden og hurtigt stødte jeg på historien om denne her kvindelige kunstner, der havde levet her, og som havde forsøgt at etablere et museum for kvindelige kunstnere. Jeg blev fascineret af hende og forsøgte at komme nærmere ind på hende ved at tale med lokale og besøge egnsarkivet. Ret hurtigt opdagede jeg imidlertid, at Anna Klindt var en stor selviscenesætter og overordentlig bevidst om, hvordan hun fortalte sin historie, og med hvilket billede hun præsenterede sig selv, når hun f.eks. blev interviewet. Indimellem fortalte hun historier, der var decideret opspind. Det gjorde selvfølgelig min undersøgelse af hende endnu mere interessant og udfordrende. Jeg var afhængig af subjektive kilder og Anna Klindts egne delvist fiktive fortællinger, og dertil mit eget subjektive 
blik på hendes liv. Det blev derfor hurtigt en sammenvæevning af alle mulige subjektive og fiktive udsagn, og det var det, der kom til at sætte rammen for udstillingen. For mig var det en interessant indgangsvinkel til at beskæftige sig kritisk med portrætgenren.

\section{Hvordan har du sat rammen for udstillin- gen?}

Jeg har forvandlet de mange forskellige udstillingsrum til 'haver', der hver for sig har relation til Anna Klindt Sørensens liv. Jeg kalder det haver, fordi Anna Klindt Sørensen havde en fantastisk have i Ry, som i dag er en offentlig park, men også fordi jeg oplever vandringen rundt $i$ hendes liv, som en vandring rundt i en tilgroet have. Man må følge snoede stier. Hendes liv var som en have, hvori der var mange mindre haver. Det er sådan udstillingen er. De 9 haver er ikke skarpt afgrænsede, men flyder sammen. På den måde er udstillingen ét samlet værk, der udgøres af de 9 haver.

\section{Hvilke traer, buske og blomster vokser der så $i$ Anna Klindts 9 haver?}

Den første kalder jeg Selviscenesattelser. Jeg har spærret indgangsdøren i foyeren af et stort udspændt lærred påtrykt et fotografi af mig, der ligger og spærrer døren. Det er en iscenesættelse af mig selv i et øjeblik fra Anna Klindts liv. Mig som Anna Klindt, der spænder ben og ligger i vejen. I både bogstavelig og overført forstand kan man ikke komme ind af hoveddøren, men må finde vej gennem en sidedør.

Et andet rum - en anden have - kalder jeg Portrettet. Her har jeg printet fotografier, hvorpå Anna Klindt optræder på halvtransparent kalke, og hængt dem på vinduerne. Men jeg har fjernet Anna Klindt. Skåret hende væk og efterladt et hul, der kan udfyldes; selvfølgelig for at pege på de subjektive mekanismer, der ligger i beskrivelsen og fortolkningen af andet menneske.
Et menneske, der i dette tilfælde ikke lever længere og derfor ikke kan forsvare sig, men er prisgivet eftertidens fortolkninger. I dette rum indgår en række af Anna Klindts egne selvportrætter.

\section{Du viser både fotografier og møbler, men og- så video og lagkagespisning?}

Ja, en filmoptagelse af Anna Klindt der vandrer rundt i sin have i Ry projiceres på endevæggen i det rum - eller den have - jeg kalder Havevandring. Størrelsesforholdet mellem hende og en selv er næsten 1:1, og det korte klip, der loopes, giver et billede af det, man kunne kalde vildnisset Anna Klindt.

I haven Livsmøbel har jeg placeret skitsebøger og forskellige møbler, hvori der er integreret f. eks. video eller lyd, og i ét rum tapetseret fra gulv til loft med unikt Anna Klindt-tapet hænger hendes selvportræt 'Søren' - et navn hun indimellem tog på sig og signerede billeder med. Og ja, jeg fik lavet en lagkage til udstillingsåbningen i målet $65 \times 120 \mathrm{~cm}$. Den var en kopi - også i skala - af Anna Klindts maleri Model ved havet. Desuden stod der på kagen forskellige udsagn om Anna Klindt og om kvindelige kunstnere generelt. Alle til åbningen fik en bid af Anna Klindt. Man kan se en video af kagedissekereringen på udstillingen og på hjemmesiden. De øvrige haver udgøres bl.a. af Anna Klindts have i Ry, der i dag er en offentlig park. Jeg har arrangeret, at man, mens man går rundt i haven, kan høre hende selv fortælle ved at ringe på et bestemt telefonnummer. Slutteligt er der det, jeg kalder Metahaven, som er kataloget til udstillingen med foto og tekster og $\mathrm{Fo}^{-}$ rum, som er en åben blog på udstillingens hjemmeside, hvor interesserede kan skrive kommentarer og tanker.

\section{Hvordan iscenesatte Anna Klindt sig selv? Hoor udspekuleret var bun?}

Det er svært at gennemskue, hvor udspe- 
kuleret hun var, men grundlæggende oplever jeg hende som meget xgte og selvbevidst. Men hun var en iscenesætter, helt sikkert. Hun fortalte f. eks. til pressen, at hun i sin tid var med til at gøre oprør og reformere kunstakademiets kønsdiskrimination. De historier blev trykt og har etableret sig som en slags sandhed om Anna Klindt, selvom hun reelt forlod akademiet allerede efter ét semester. Hun har formået at placere sig selv. Hun har plantet et frø, men det er alle mulige andre faktorer, der har vandet det og fàet det til at gro, f. eks. dem der skriver hendes historie og måden hvorpå, de skriver den. Alle Anna Klindts breve er blevet brændt, og en sandsynligvis vigtig kilde til at forstå hende og lære hende at kende er derfor utilgængelig for altid. Der er nogle ubekendte størrelser i ligningen, og mekanismerne omkring disse er interessante ikke mindst for min egen praksis. På min udstilling er der derfor allerede fra begyndelsen meget flydende grænser for hvem der taler: er det mig eller Anna Klindt eller beskueren selv? Den bliver i ligeså høj grad et portræt af mig selv. Jeg gør det klart fra begyndelsen, at jeg er dybt indblandet, og at det objektive portræt er en illusion, ligesom man bør stille spørgsmålstegn ved den skrevne biografis autoritet.

Anna Klindt benyttede $i$ flere tilfelde feministisk strategi, f.eks. signerede hun nogle billeder som Søren, angiveligt for at opna en rimelig salgspris. Har du selv oplevet, at visse dore har veret lukket pga. dit køn? Pagair diskriminationen $i$ dag?

Ja, det gør den. Men det er ikke dét, der har været udgangspunktet for projektet. Det er ikke lavet ud fra en bitterhed, men ud fra en interesse for de mekanismer, der ligger udenfor en selv. Udstillingen beskæftiger sig med generelle problematikker, og kan ses af både mænd og kvinder. Det er muligt, at mine mandlige kolleger har lettere ved at sælge værker, få udstillinger, og at visse stemmer præsenterer og stereotypificerer mine og andre kvinders værker i forhold til kvindekønnet og regressive forestillinger om kvindekunst, men jeg oplever ikke, at det er en drivkraft hos mig. Dertil skal dog siges, at man ikke altid er i stand til at se hvilke mekanismer, der gør sig gxldende i ens eget liv - som min udstilling også viser. Asger Jorn sagde engang, at den kunstneriske udvikling aldrig har været resultatet af kunsternes kritik og kvalitativ udvælgelse men af kvantitativ overflod. Med det vil jeg sige, at jeg ikke tror det skader, at både mænd og kvinder bidrager til vores kultur. Men selvfølgelig har det påvirket mig, at vi står på skuldrene af en maskulin kunsttradition. Mange af de kunstnere, jeg har haft som forbilleder, er mænd, fordi kvinder ikke har eksisteret i kunsthistorien før i nyere tid. Det kan selvfølgelig have influeret mig, og det er interessant at overveje, om jeg havde lavet andre ting, hvis jeg i mit første møde med kunsten havde mødt flere kvindelige kunstnere - eller udelukkende kvindelige kunstnere.

Anna Klindts ide om et kvindekunstmuseum $i$ hendes hjem blev ikke realiseret. I dag har vi kvindemuseet $i$ Arbus, der $i$ højere grad er et kulturhistorisk museum end et kunstmuseum. Har du nogle kommentarer til dette? Er tanken om et museum udelukkende for kvinder grundlaggende regressiv?

Jeg tror, at det bedste man kan gøre for kvindelige kunstnere er at formidle dem. Det man ser, kan man skrive om. Eller lave en udstilling om. På den måde kan man skrive kvinderne ind i historien. Det er en meget basal og pragmatisk betragtning, men det er dét, jeg gør her. Jeg bringer problemstillinger omkring det at være kvindelig kunstner på banen, men jeg gør det lidt skjult. Det ligger indbygget og subtilt og står ikke ud som en løftet pegefinger eller en bitter grundtone. 
Hoad skal man gore for at bekampe den manglende ligestilling $i$ kunstverdenen?

Det er der ikke nogen let løsning på, men det vigtige er, at man er bevidst om, at de mekanismer der pågår, de diskurser og traditioner man indskriver sig $i$, at de er maskuline. Og så må man prøve at handle i forhold til mekanismerne, så godt man kan. Jeg tror ikke, at løsningen er, at kvindelige kunstnere skal maskulinisere sig for at opnå anerkendelse, men jeg tror heller ikke, den er at overfeminisere sig ved at hævde, at ens påståede kvindelige egenskaber er kvaliteter på lige fod med de egenskaber, der tillægges mænd. Jeg tror, at det centrale er at være bevidst om, at både kvindelighed og maskulinitet er defineret indenfor et maskulint regime og værdisæt. Jo større bevidsthed der er om det, jo lettere tror jeg, det er at navigere, både som mandlig og kvindelig kunstner.

\section{FAKTA}

Anna Klindt Sørensen (1899-1985) var ekspressiv maler og grafiker. Hun kom fra Ry og levede størstedelen af sit liv dér. Anna Klindt Sørensen studerede på porcelænsmalerskolen i København og blev senere optaget på Kunstakademiet i København (1919), som hun dog hurtigt forlod i protest mod akademiets konservative undervisning til kvindelige studerende. Efter en periode i Paris, nåede hun at opleve stor anerkendelse som kunstner og modtog i 1963 Eckersberg Medaillen og i 1976 Thorvaldsens Medaillien. Anna Klindt

Sørensen var feministisk engageret, internationalt orienteret og selvbevidst; hun blev aldrig gift og fik aldrig børn og hendes testamente tilgodeså kvindelige kunstneres sag. I sine sidste år var hun optaget af at oprette et museum for kvindelige kunstnere i hendes hjem Petersborg i Ry, hvilket dog aldrig lykkedes. Hendes have er i dag offentlig tilgængelig park i Ry.

Birgitte Kristensen (f. 1975) er uddannet billedkunstner fra Det Jyske Kunstakademi, 2002 og har senere studeret semiotik og æstetik. Hun arbejder tværmedialt ofte med relationelle, konceptuelle og sociale aspekter.

Birgitte Kristensen: Anna Klindts 9 Haver

KunstCentret Silkeborg Bad

Indtil 26. april 2009

Tirs-fre 12-16, lør-søn 11-17

Desuden udstillingselementer på

www.annaklindts9haver.net samt i den offentlige have ved Petersborg i Ry, hvor man under havevandring kan høre Anna Klindt Sørensen tale ved at ringe på tlf. 99400760

Interaktiv formidling på Kvindemuseet i Danmark. Tirs-søn10-16, ons10-20.

Ane Bülow, cand.mag i kunsthistorie Billedredaktør på Kvinder, Køn \& Forskning 